\title{
The Pre-Colonial Socio-Economic Practices of the Khayo Community of Busia County in Western Kenya
}

\author{
Kaunda Kenneth K. Odulwa ${ }^{1}$ \\ Dr. Peter Wafula ${ }^{2}$ \\ Dr. Charles Choti ${ }^{1}$ \\ ${ }^{1}$ Department of Languages and Humanities, Mount Kenya University \\ ${ }^{2}$ Department of Humanities, Kenyatta University \\ DOI: 10.29322/IJSRP.11.09.2021.p11725 \\ http://dx.doi.org/10.29322/IJSRP.11.09.2021.p11725
}

\begin{abstract}
The Khayo is one of the seventeen subtribes of the luhya community. "Abaluyia" is the preferred name for the people once called "Bantu Kavirondo". It is a subtribe of the Luhya people of Kenya who reside in Busia County. Little is known about socioeconomic transformation of this subtribe. Most of the available literature does not give an account of the Khayo during the pre-colonial, colonial and post-colonial periods. Thus, this study entailed unraveling the pre-colonial socio-economic practices of the Khayo Community of Busia County in Western Kenya. The study adopted ex post facto design. Using primary sources including key informant interviews. Secondary sources of information included journals, textbooks and note-taking. The sample population comprised various age groups obtained using purposive sampling and snowballing techniques. Data analysis was done by identifying common themes. The study findings show that various activities were associated with social and economic practices among the Khayos in the pre-colonial periods. The social aspects included each family staying together in a homestead, mostly in grass-thatched houses; men and sons were always considered superior to women and daughters; marriage was viewed as sacred where polygamy was allowed; the Khayo believed in 'Were khakaba' and ancestors. The economic activities included community land systems, peasant commodity production with specific areas being hunting, crop production, animal husbandry and barter trade.
\end{abstract}

Key words: Pre-Colonial, Socio-Economic Practices, Khayo Community, Busia County, Western Kenya

\section{INTRODUCTION}

Historical studies of the colonial era in Kenya, as elsewhere in Africa, have gone through two major phases. Prior to the 1960s African history in general meant the study of Europeans, Arabs and Asians in the region. Consequently, studies of the colonial period paid most attention to the policies of the colonial governments or the activities of the immigrant communities. Africans were depicted largely as passive participants in the process of economic transformation (Abuso, $1980 \&$ Bode, 1973). The early colonial administrators and anthropologists who carried out studies on Kenyan societies dealt with migration and settlement (Ajayi, 1968 \& Ogot, 1976). Before the arrival of the Europeans education in Kenya informal education was an important factor through which the young ones came to know how to utilize the surroundings.

Economically, division of labour was instilled in the young ones who came to know what was expected of them. Role models and values were inculcated and reinforced; ceremonies like circumcision and age set prepared the young ones for adult responsibility. Traditional education was both informal and formal and had direct link to perpetuation and elaboration of economic studies. Other social practices as religion played an important role in the day-to-day life of the western Bantu people and was organized as the pillar of the community and continuity of human life. The Khayo religion recognized ancestral worship with strong belief of life after death. The community belief in life after death rested in the premises that though man dies his spirit continues to live, he protects and his spirit cares for his family, relatives and even friends hence becoming the guardian angel of the living (Ogot, 1976).

It is not possible to write the whole history of social economic transformation of Kenya during the colonial period without tracing the socio-economic transformation of tribes and subtribes, Khayo included. The Khayo was among the first Luhya groups to feel the impact of Christianity or missionary work when Catholics and Anglicans established mission stations at Kisoko and Nambale. However, they

This publication is licensed under Creative Commons Attribution CC BY.

http://dx.doi.org/10.29322/IJSRP.11.09.2021.p11725

www.ijsrp.org 
were slow to embrace Christianity and take advantage of the socio-economic changes it brought about. Thus, the slow adjustment compared to their neighbors need to be understood.

The Khayo is one of the seventeen subtribes of the luhya community. "Abaluyia" is the preferred name for the people once called "Bantu Kavirondo" because of their proximity to Lake Victoria's Kavirondo Gulf. "Abaluyia" refers to a nation, tribe, or ethnic group. "Omuluyia" refers to an individual and "Luluyia" is the language they speak. Khayo lives in Busia County which is situated in Western Kenya and serves as the gateway to Kenya's regional neighbors including Uganda, Rwanda, Burundi, DRC Congo and Southern Sudan, with two border crossing points at Busia and Malaba Towns. Busia County is predominantly inhabited by the Luhya and Teso speaking people. Other inhabitants include the Luo, Kikuyu, Somali and Kisii. Most of the residents of Busia County are Christians, although there is a significant population of Muslims in the urban centres.

Khayo is a subtribe of the Luhya people of Kenya who reside in Busia County. The people who form this Luhya subtribe are referred to as the Abakhayo. Their geographical location is Ebukhayo while their language is Olukhayo. The Bakhayo borders the Wanga on the Southeast, Bukusu on the East, Samia on the West, Marachi on the South and Iteso on the North. They have so many clans like Baguri, Bakhabi, Bamenya, Bakangala, Bakhero, Baamani among many others. The Bamenya, Baguri, Bakimo, Bachabe and Bakhero clans were the first ones to arrive in Bukhayo. The Khayo speak Lukhayo and occupy Nambale and Matayos Sub-Counties of Busia County, Kenya. The Khayo refer to themselves as Bakhayo, their dialect as Lukhayo, and their land Bukhayo. Bukhayo is divided into East, West and Central Bukhayo locations with Nambale, Matayos, Busibwabo, Mungatsi and Mabunge as their significant trade centres (KNBS). According to Tim Wambunya (2007), the Khayo is named after Were Mukhayo, who led Abakhayo from Busoga to Ibanda. Between A.D 1598 to 1733 there was large scale immigration of the Khayo from the area of origin through eastern Uganda and Buganda (Ogot, 1976).

Little is known about socio-economic transformation. Kenya consists of many ethnic groups with varied cultures. Studies of all ethnic groups should be conducted in order to understand the history of Kenya. It is asserted that the pre-colonial African states had evolved a diversified economy which was self-sustainable. Barter trade helped to supplement the shortfall. Colonialism caused African economies to be dependent on the metropolitan economy. The pre-colonial economies were either destroyed altogether or modified. As in all Kenyan ethnic groups, there are a few written sources concerning the pre-colonial era and any meaningful reconstruction requires extensive use of oral literature. Most of the available literature does not give an account of the Khayo during the pre-colonial, colonial and post-colonial periods. Studies in socio-economic transformation have been necessitated by the need to understand the fact that colonialism had an impact within communities, including Bukhayo. Therefore, this study examined the precolonial socio-economic practices of the Khayo community of Busia County in the period 1890-2010.

\section{RELATED LITERATURE}

Nwankwo (2012) focused mainly on colonialism and its impact in Africa without highlighting the pre-colonial and post-colonial periods. On the other hand, Ogot (1976) focused on the social and political organization of the Luo. To bridge the gaps the need for the current study seemed evident, hence the focus on the socio-economic changes of the Khayo between 1890 and 2010.

Colonialism and its legacies continue to attract scholarly attention (Kitching, 1980; Mamdani, 1996; Wrigley, 1965 and Wolff, 1974). For a number of scholars colonialism has had a powerful and lasting impact on Africa. Crawford (1995) states that the overall colonial legacy cast its shadow over the emergent African state system to a degree unique among the major world regions.

The Ghanaian historian, the late Adu Boahen, preferred a middle course in Akurang, (2006) reiterating that in some respect the impact of colonialism was deep and certainly destined to affect the future course of events. This study addressed the effect of colonialism at large while the current study focuses on socio-economic changes of the Khayo between 1890 and 2010.

Eelke (2009), in his review of religious values and economic growth found out that social activities like meetings of football clubs can be instruments for establishing networks that could initiate economic activities. This could also be helpful for establishing trading relations with partners from other countries. However, Davidson (1983) argues that after the First World War, the victorious colonial powers used violent and punitive taxation methods to exploit Africans. He also expresses that Africans could provide for their needs by working for themselves as farmers or craftsmen and, therefore, they saw no advantage in going to work for monetary wages.

Hallet (1988) asserts that in 1875 most of the East African communities were locked in the straitjacket of a subsistence economy and therefore totally unaware of the challenging experience common to so many people of North and West Africa. He points out that a subsistence economy depended on the local environment. To him the basic theme of the East African economic history during the colonial period was to be found in the removal of the then constrictions, the development of a more efficient system of communication and the introduction of new forms of agricultural produce easily saleable on the world market.

This publication is licensed under Creative Commons Attribution CC BY.

http://dx.doi.org/10.29322/IJSRP.11.09.2021.p11725

Www.ijsrp.org 
Munro (1984) argues that there was no clear or appropriate yardstick by which economic change in colonial Africa may be judged. Whether in terms of economic growth and welfare as conventionally measured by output in per-capita and improvement in real incomes over time, or in terms of creation of economic conditions conducive to political independence, national self-reliance and self-respect, or in terms of historical materialism, the development of modes of production, leading to class struggle, and the potential for a transition to socialism there is not a clear yardstick. According to Munro, disagreement over the historical record, as well as a great deal of confusion of purpose, has arisen from the interplay between these very different approaches to the evaluation of the past. He contends that the pioneering academic assessment appearing between the two World Wars - when colonialism was firmly established and when it was most secure - emphasized the activities of British administrators, businessmen and settlers in the opening of Tropical Africa to 'imperial and international trade, and in creating a monetary economy in regions assumed to be dominated by subsistence production and barter exchange. Pre-colonial history was largely ignored, and Africans tended to be depicted largely as passive participants in the process of economic transformation initiated and controlled by the outsiders.

According to Boahen (1990) the relation between Africans and Europeans did undergo a revolutionary change and Africa was faced with a serious colonial challenge between 1880 and 1935. Brett (1961) sought to evaluate what of the old was retained and what was destroyed and what adaptations and accommodations were made. In the conservative orthodoxy which dominated the study of African economic history, it was the imposition of direct European rule which primarily brought about the transition from primitive, subsistence systems to modern, market-oriented production and exchange.

Ralph (1987) asserts that despite all the reservations, it is impossible to deny that dramatic changes did take place in Africa as a result of colonialism. The economy of the mid-20th century was very different from that of the past. The European government created new infrastructures of administration, transport and social services, all of which influenced all aspects of exchange and production. Ralph also argues that colonial rule created the possibility for direct appropriation of African productive resources by Europeans and the relegation of Africans to the status of proletariats.

\section{Theoretical Perspective}

The study was guided by the Dependency Theory of the early 1970's, as argued by Walter Rodney, a fairly typical dependency theorist and articulator of modes of production. Dependency Theory states that 'colonialism and neocolonialism have created unequal economic relations between poor and wealthy countries. Rodney argues that a combination of power politics and the economic exploitation of Africa by Europeans led to the poor state of African political, economic and social development evident in the late $20^{\text {th }}$ century. The only path to true human development and liberation for the majority of people was through the transformation of their own lives, in a struggle to replace and shape the neocolonialist government that dominated their society.

Power is the ultimate determinant in human society being basic to the relations within any group and between groups. It implies the ability to defend one's interest and if necessary to impose one's will by any means available. In relations between peoples, the question of power determines maneuverability in bargaining the extent to which a people survive as a physical or cultural entity. When one society finds itself forced to relinquish its power entirely, that is a form of underdevelopment. The Dependency and Underdevelopment theories have been used in this study with a view of analyzing the transformations in social and economic activities among the Khayo of Western Kenya from 1890 to 2010.

Among some of the social and economic activities discussed are clannism, birth, marriage, religion, agriculture, education, technology, labor, population, trade and the traditional legal system. Articulation of modes of production theory has also been applied in this study to demonstrate the impact of the capitalist mode of production on the pre-capitalist mode of production. The incorporation of the precapitalist mode of production resulted in a historical relationship which tended to dissolve undesired elements while conserving useful elements in the former. The process of the integration of Khayo's pre-colonial economy with the colonial capitalist economy involved the use of coercive and non-coercive powers. Coercive power involved unleashing violence on the people by the colonial administrators, seizure of livestock and punitive taxation.

Non-coercive power involved establishing institutions of chiefdom as an instrument of co-optation and local control. The process of integration led to the dissolution or distortion of certain features of Khayo's pre-capitalist social and economic set-ups while conserving desirable institutions for the purpose of enhancing the functionality of capitalist activities in the region. The colonial capitalist policies introduced in the Bukhayoland resulted in social and economic changes among the Khayo. The underdevelopment theory gives insights into the socio-economic changes of the Bakhayo people. Radical transformation from colonial structures brought some socio-economic change.

\section{METHODS AND MATERIALS}

The study adopted ex post facto design because the facts were narrated as they are without alterations. Data was collected from primary and secondary sources. Primary sources included key informant interviews. Secondary sources of information were journals, textbooks This publication is licensed under Creative Commons Attribution CC BY. 
and note-taking. The sample population comprised various age groups obtained using purposive sampling and snowballing techniques. Data analysis was done by identifying common themes from the respondents' descriptions of their experiences. The data obtained was analyzed thematically along the study objectives.

\section{STUDY FINDINGS}

\section{Origin, Migration and Settlement of Luhya}

Precolonial ethnic migration in Kenya like all other African societies, is vast with limited available evidence. Furthermore, the little evidence found is scanty and disjointed. According to Were (1968), the early history of the Luhya is very complex because there were great ethnic differences among the early settlers. The Abaluyia are a hybrid community founded by people of varied origins and cultures. They came from all directions to settle in Buluyia.

Were (1967) noted that the Luhya established themselves in Western Kenya by A.D. 500. Also Were (1968) noted that between 1598 and 1733, there was large scale migration from the Bantu areas of eastern Uganda and Buganda. Ancestors of the majority of presentday localities such as Tiriki, Wanga, Bukhayo, Samia, Marama, Bunyore, parts of Kabras, and Marachi arrived about this time. During the period 1580 to 1650, the locations of the Tiriki, Marachi, Bukhayo, Wanga, Maragoli, Samia, Marama and Bunyore were occupied by most of their present-day inhabitants.

Though the Luhya are said to have moved up from the Bantu areas of neighboring eastern Uganda, tradition also suggests that they originally came from "Misri" (Egypt), but there is no other evidence to support this. Anthropologists believe that the Luhya were part of Bantu expansion out of central Africa. Around 1000 BC the Maragoli oral traditions point at Misiri (Egypt) as their cradleland.

Most of the Luhya sub nations are from the present-day Uganda as narrated by Kelvin Wesonga during an oral interview (O. I 2014). The most powerful centralized kingdom was founded by the Wanga who incorporated most of the Luhya nations. Before the advent of colonialism, ethnic groups in Africa defined boundaries based on the occupation of territory by a community with similar language (Mukhule, 2008).

Desire for more land and an invasion by tsetse flies led to Luhya migration. Some migrants moved straight into Buluyia, while others went south to the lake region. When the Luo came, they pushed the Luhya further north and south (Were, 1968). Khayo are a Luhya subtribe referred to as the Abakhayo. Their geographical location is Ebukhayo while their language is Olukhayo. The Bakhayo border the Wanga on the Southeast, Bukusu on the East, Samia on the West, Marachi on the South and Iteso on the North as narrated by Thomas Ouna (O.I, 2014).

One among the sub-groups of the Bakhayo who the majority and the first settlers were to come is the Abaruguri. Other clans include: Abashtohe, Abamwaha, Abakhibe, Abadiru and Abamukwe then Abamenya, Abachimo and Abade then Abakhabi, Abakhome, Abahamani, Abarunga, Abamakunda, Abakangala, Abakhadonyi, Abakholo and Abamudiru. Originally Khayo lived L. Victoria at Ibanda in Busoga, after which they travelled and reached Khaenderesi in south Iteso in Busia County, then Sirabale to Bukhayo. This information was obtained from Brenda Ajiambo during data collection. The reasons for migration included attacks from elephants, sleeping sickness, overcrowding and family conflicts.

When the Bakhayo reached Ibanda, they intermingled with Teso, which led to adoption of cultures from others as shared among the neighboring groups. Therefore, the period between 1500 and 1800 appears as one of general restructuring of social and political units and formation of new social allegiances. The immigrants in the process disrupted older accommodation and patterns of life. In the precolonial era, though the Khayo were chiefly agriculturalists, they also kept livestock, practiced hunting and food gathering. They also involved themselves in several crafts, industry and trade as narrated by Bonface Okodoi (O. I, 2014).

It should be noted that during most of the pre-colonial period, the Khayo economic organization was not stagnant or static but quite the contrary. People had in the previous centuries witnessed rapid economic change and transformation due to migration, hence the consequent changes in the production system and trading patterns. Like other agricultural communities in the world, land was very important to the Khayo (Carlsen, 1980). They were deeply attached to it, and as Muriuki (1976) argues in the case of the Kikuyu, it was more than an economic asset.

\section{Social Organization of the Bakhayo in Pre-Colonial Era}

Khayo had a strict culture that guided and regulated policies for its people. In the early days, each family stayed together in a homestead. They lived in grass-thatched houses. Leaders were chosen from within the clan's wise men by the council of elders who ruled them. The council of elders apportioned responsibilities to men, women and children. The father was the head of the family and carried out all the hard manual work. He provided shelter for the family and met all its needs and demands (Mukhule, 2008). He also looked after cattle and ensured that his family members were disciplined.

This publication is licensed under Creative Commons Attribution CC BY. 
The man also cut and harvested the reeds, made ropes for tethering cattle, goats and sheep, milked the cows and went after cattle raiders. Men were also hunters and gatherers and had a taste for wrestling matches.

The functions of the clan elder (omwami) were numerous, including protecting the people, maintaining law, order and peace, and generally attending to the welfare of his people, settling cases and receiving the fees, as well as performing certain sacrificial duties. The council presided over family ceremonies, settled disputes and formulated laws governing the community (Ogot, 1976).

During the pre-colonial era, men and sons were always considered superior to women and daughters as noted by Justus Mulianga from Bukhayo Central in an oral interview (O.I, 2014). The family was mainly extended, where blood relationship was highly regarded (Okodoi, O.I, 2014).The clans enforced the customary laws using a council of elders (Ogot, 1976). These laws were passed over from generation to generation, according to the field study findings. This was noted by Judith Nabwire (O.I, 2014) from Nambale Township and Chitechi Fatima (O.I, 2014) from Bukhayo North. Tales were told to the young by grandparents who touched on issues such as eating habits, discipline, bathing, washing clothes, and rejection of vices such as premarital sex and alcoholism. The family was united and strengthened through regular family meetings (Mukhule, 2008).

Marriage was viewed as sacred among the Khayo and people married for procreation and companionship. Virginity of the bride was highly valued and rewarded at the time of marriage (Mukhule, 2008). Barasa Makokha (O.I, 2014) from Bukhayo East pointed out that indeed the Khayo intermarried with the Marachi, Luo, Samia, Bukusu and Teso. This is in consistence with literature that shows that the Bakhayo have interacted, intermingled and intermarried with others in their history (Ogot, 1976).

More so, polygamous marriage was allowed, provided the man would take care of his wives and children without discrimination as Alice Namkuru (O.I, 2014) of Bukhayo Central noted. According to elders, global changes and other events like droughts and famine determined the names of the Khayo children. Seasonal names were given as affirmed by Mary Nyongesa (O.I, 2014). Initiation took the form of the removal of six (6) lower teeth among the clans in Bukhayo. These views were given by Muga Bwire (O.I, 2014) from Bukhayo East. Drinking of local brew by elders accompanied most social ceremonies.

The Khayo believed in 'Were khakaba' and ancestors. They indulged in the adoration of ancestors, offered libation and performed sacrifices to appease the spirits of the dead. These views were expressed by Margaret Ndeda (O.I, 2014) from Bukhayo Central. Indeed, according to Ogot (1976), the Khayo religion recognized ancestral worship with a strong belief in life after death. The study also established that religious leaders included medicine men, sorcerers and religious personages.

Martha Ikasereng (O.I, 2014) from Bukhayo Central and Pascal Omuse (O.I, 2014) from Walatsi location noted that the Bakhayo believed that the role of their ancestors was to protect the community, reward good people and punish the wrong doers. Thus, the Emakina, Odangita, Nganga and Obilo caves acted as places of ancestral consultation.

\section{Pre-Colonial Economic Practices}

Khayo were both pastoralists and farmers in the early days. Due to scarcity of land, they have remained farmers, according to Richard Wandera (O.I, 2014) and George Hinda (O.I, 2014). It could be argued, as Hopkins (1973) did in the case of West Africa, that the indigenous economy experienced major historical changes that exhibited regional and occupational diversity. Khayo's economic practices through time were influenced by interactions between themselves and visitors, where they either borrowed or adopted other communities' practices (Ogot, 1957). The Bakhayo like other Bantus, upon migration brought with them subsistence practices centered on the cultivation of grains, root crops, pulses and bananas. They kept some livestock but only milked them: they did not breed their cattle (Were, 1967). Land belonged to the man and only boy children could inherit it from their fathers.

\section{Hunting and Gathering}

According to Ogutu \& Kenyanchui (1991) the economic practices of the pre-colonial era included hunting and gathering as a part time or seasonal mode of production practiced among the larger African traditional communities. The focused discussion groups affirmed that hunting was very common in the old days. Often people hunted to get meat. The animals hunted included rabbits, hare and antelopes. Fishing was done in the big permanent rivers.

According to Abdulkarim Makokha of Busibwabo (O.I, 2014), young men hunted in the forest to get while meat. Hares, porcupines and antelopes were hunted regularly. Methods used for hunting included hunting pits, sharp spikes, arrows, spears, dogs and sharp knives made from iron. The meat obtained was shared amongst the hunters. Each hunter received a share to take home at the end of the day depending on the catch. Honey hunting was also done by men at night using fire and smoke. Every man was a honey hunter as asserted by informants. 
Bird trapping (particularly the quails) was important, while the food gathered included mushrooms, ants, wild plants and fruits (Ogutu \& Kinyachui, 1991). The Khayo also practiced gathering of several wild fruits which were eaten by different groups of people. Vegetables were gathered by women in the forest as they gathered firewood. Some of the vegetables gathered included nettles, arrow root leaves and cow peas.

\section{Crop Production}

Agriculture was the matrix to which all other indigenous economic activities were set. Furthermore, it was not possible to give up farming in order to engage full time in other occupations, such as craft manufacture and food collection. Instead, it was the agricultural surplus that made this part-time occupation possible (Wagner, 1939). Subsistence agriculture was, therefore, the basis of pre-colonial Khayo economy (Willoughby, 1989). Of the various geographical factors shaping their agricultural activities, the most important two were undoubtedly the rich fertile soils and well distributed pattern of rainfall. In their subsistence agricultural endeavors, the Khayo had only digging sticks and later iron hoes with which to cultivate the land (Willoughby, 1989). During most of the pre-colonial period, the Khayo used the shifting method of agriculture as their principal system of cultivation (Pierre, 1956).

This was possible because, in the earlier pre-colonial periods, land was abundant due to low population. However, as the population grew and land became scarce, the Khayo were forced to settle down and abandon the system of shifting cultivation in favour of a permanent one. According to Were (1967), the changes had their roots in significant difference of economic emphasis among people who settled around the mountain region and those in the lake region. Upon migration the Bantu settlers brought with them subsistence practices centered on cultivation of grains, root crops, pulses and bananas. According to Barasa Makokha (O.I, 2014), mixed farming and shifting cultivation were practiced.

Iron hoes were used for digging and cultivation. Planting was mainly done by broadcasting of seeds during cultivation. Seeds were dried and preserved using wood ash. Married women provided labor by working on the farm.

The Khayo grew grains, pulses and root crops such as cassava, arrow roots, potatoes and yams, as well as legumes like beans and peas. They also practiced fishing. They used hooks and lines, basket nets and fence traps to catch fish. They sold some of the fish they caught to neighboring communities according to Margaret Ndeda (O.I, 2014).Through time, from 1000 to the present, more crops were introduced along with other practices, but what stood out was the Bantu influence on the Kalenjin on banana growing. For most of the pre-colonial period, the principal crops grown were grains such as sorghum, sweet potatoes, bananas and various greens. There were two seasons for planting, that is, during the long rains in April and short rains from August to November as noted by Wagner (1970).

\section{Animal Husbandry}

Animal husbandry also played a vital role in the economic organization and productivity of the Khayo. As in the case of the Kikuyu (Kenyatta, 1961) cattle in Khayo community was, in the first place, a display of wealth. Secondly, cattle had important economic use which included the provision of milk, meat, blood (boiled and used as soup) and skins used for clothing, bedding and sandal making. Cattle were also in payment of dowry and more importantly, a man of full adult status had the right, if his own crops failed, to barter part of his livestock (particularly cattle) for grain or other foodstuffs which he needed so as to sustain his family. Likewise, a man could slaughter a cow at his homestead and barter the meat for baskets of grain (Wagner, 1970). Apart from cattle, the Khayo also kept sheep and goats. Sheep were mainly used for sacrificial purposes, though they were also used for trading. Goats were important for providing milk, meat and skin (for clothing), as noted by Wilson Namenge (O.I, 2014). According to Wilson the Khayo also had fowls that were kept in nearly every homestead which were valuable for their eggs and as a source of meat.

Indigenous chicken, goats, sheep and cattle were kept according to interviews conducted. Larger herds of cattle symbolized wealth as affirmed by Rael Wesonga (O.I, 2014). This is in agreement with Ogutu (1991) findings that Khayo practiced animal keeping. Kevin Wesonga (O.I, 2014) indicated that cattle were mainly kept for milk, manure, meat, ploughing, and transport. Sheep were kept for meat and cultural activities while goats were kept for meat. He added that, indigenous poultry was practiced for eggs, meat and cultural practices while quails were kept for meat. Thus, the Khayo kept cattle, sheep and goats, which provided them with milk, meat, hides and skins. Communities engaged in such activities to meet their subsistence demands and to produce surplus to be disposed of through trade so as to acquire other commodities not readily available to them.

Young men took livestock to graze where pasture was available. Livestock was valued for meat, milk, fat, blood, horns, skins, dung and also status. Bulls, rams and goats were slaughtered for meat to be eaten on social occasions like childbirth and marriage ceremonies. In addition, butter was obtained from fermented milk done by women using guards. This fat could either be eaten or used for softening skins to make clothes. Blood was obtained from live bulls. Drawing of blood was done by men specialized in the same and hired at a fee. Livestock provided clothing; hides were tanned by men who used a stone to soften them. Goat skins were preferred since they were 
softer and more durable. Women and girls dressed in goat skins while men wore clothing made from cow hides. Skins were also used for bedding and making ropes and bellows for iron workers.

Additionally, horns were used to make trumpets, musical instruments and drinking vessels. Cow dung on the hand had several uses including: smearing on the walls of huts, sealing holes on storage containers and winnowing baskets, as well as manure. Cattle were also used in paying dowry, besides being a symbol of wealth. Livestock was also used in barter trade for other commodities. It was also used during food shortages as an alternative food supply or exchanged for grains. This information was obtained from an interview with Brenda Ajiambo (O.I, 2014) of Bukhayo East. During the pre-colonial period, African economies were dynamic and as such just like many communities in Kenya ecological niches forced a number of them to adjust their practices (Sheriff, 1985). The Bakhayo were not exceptional. Production was primarily for collective subsistence rather than individual accumulation which in turn influenced the kinship system.

\section{Trade}

It is also important to look at the systems of trade and exchange and find out if they were important in the whole arrangement of economic production and organization (Wagner, 1970). It should be observed from the onset that, the traditional Khayo family was essentially self-sufficient, unless rare and abnormal occurrence like drought, hailstone or prolonged sickness occurred upsetting the family food reserves. When this happened, the family had two options, either it could rely upon the members of its kinship group for assistance or, as a last resort, took to trade and exchange of animal and other material goods for grain and other foodstuffs. Thus, the system of mutual obligation tended to minimize the need for a market. There was one word some local trade (Hugh, 1985).

The Luhya subgroups practiced trade among themselves in the pre-colonial era. Iron hoes, spear points, and ivory, for example, could be traded for grains or animals. Pre-colonial trade covered a distance of no more than 72 kilometres, since there were three pre-colonial markets where Luo, Nandi, and Abaluyia came together to trade baskets, wooden tools, quails and various foodstuffs from cattle, fish, tobacco, and so forth. Hence despite their sometime conflictual relations they interacted amicably (Wright, 1979).

Such trade existed in the fields of crafts and industrial products (in some cases specialist worked to order) which were exchanged for fowl, goats, sheep or cattle. Cattle, sheep and goats were also exchanged with more valuable objects of iron or else as for service rendered or received. Therefore, trade and exchange played a less significant role in the system of economic production and organization. Indeed, most craftsmen pursued their crafts more as a hobby rather than as a profession.

This was partly due to the fact that the skill required for any craft was simple and therefore many adults knew something about one or two of the traditional technologies. This had several effects including a low number of customers for every craftsman and therefore, apart from the medicine practitioners, whose occupation required a higher degree of training, skill and personality, craftsmen received very low profit from their occupation (Wagner, 1970).

Although cattle were regarded as a measure of wealth (Painter, 1951), they alone could not transform a subsistence economy into an exchange one. The exchange value of other goods increased with the offer of desirable goods or services by a foreign community. This produced corresponding demand for goods produced by the community economy. Surplus produce was exchanged with what they lacked from the neighboring communities resulting in local trade.

From local trade developed regional and later long-distance trade which involved a variety of goods. This however influenced society minimally (Ndege, 2009). This was confirmed in an oral interview that; barter trade was commonly practiced amongst the community members as well as with their neighbors, Brenda Oseben (O.I, 2014). However, there was no long-distance trade practiced. The Luhya for example gave their Nandi and Luo neighbors, grains, iron implements and soap-stones in exchange for livestock, salt, hides, milk, pots and baskets. Ironworking enabled the Khayo to have better weapons. They were also good in pottery and basketry, which boosted their trade and other economic activities.

\section{Technological Process}

Various early industries in the Khayo community included iron working, pottery, cloth manufacture and basketry. There was division of labor based on gender. Women dominated in pottery, castor oil manufacture and basketry.

\section{Iron working}

This was done by men. Smelting of the ore was done in a big furnace using charcoal as the source of heat. Charcoal was burned in the forest by a group of iron workers. Wives collected and transported the charcoal to the smelting area. Goat skin bellows were used to blow air into the furnace until the flame glowed blue. The melting process would take a whole night. Iron worker would then forge the piece of metal into the required shape by hitting it with a hammer. A whetstone was used to sharpen the implements. The iron obtained 
was used to make agricultural implements which included pangas, knives, axes and hoes. The weapons made from the iron included swords, spears and arrows, used for security. The ornaments made from iron were leg jiggles, earrings, finger rings and necklaces.

Other iron products made were small knives used for circumcision, and or shaving, arrows used to draw blood from live bulls, cow bells and branding tools. Iron workers were respected in many African societies. They were the wealthiest members in the various communities. Young men learned the skill through apprenticeship at a fee paid in goat form. This information was narrated by Odulwa Morris: (O.I, 2014) of Busibwabo location.

\section{Pottery and other Handiworks}

This was both a specialized and localized art amongst the women. It was restricted to women of specific communities. Pottery was practiced in areas with clay. The art was secretive so that other members of the society could not learn it easily. It was done on cooperative basis to share the cost of the firewood used. This information was obtained from an oral interview with Mary Nyongesa (O.I, 2014). The Khayo engaged themselves in various technological processes. The most important ones were house building, making of garments and bedding, pottery, basketry, woodcarving, iron work, and string and thread making.

However, the making of cloaks worn by important elders and the repair of ordinary skin garments was only undertaken by specialistsabanabi, as noted by Okapel Josphat (O.I, 2014). In the case of pottery, basketry, woodwork, ironwork and string and thread making, there was a substantial amount of specialization and trade in them. In pottery, all the work, from start to finish, was done by women. Most of the pottery products were bartered or exchanged for grain, goats, sheep or even cattle (Hugh, 1985). Basket work was characterized by the solid and substantial appearance of the objects and the uniformity of shapes and styles. It was essentially a man's work. A reed called makhindu that grows near rivers was the main material used in basket work, although tsinundu, a plant growing widely, was also used to make baskets as affirmed by Morris Odulwa (O.I, 2014).

Woodwork was another occupation undertaken by specialists, although objects like handles for hoes and knives required little skill and therefore a good number of men had some knowledge. Objects made from wood included various kinds of stuff, scoops, mats and vegetable bowls, stirring paddles, threshing paddles, jugs, stools, beehives, mortars, pestles and digging sticks (Wagner, 1970).

The most important objects made from iron were weapons like spears, bows and arrows, knives, razors, hoe-blades, axes and cow bells. Others were armlets, bracelets, necklaces, finger rings and coils. Most of these products were exchanged for grains, cows, goats and sheep. Other products of the traditional technological processes, particularly the string and thread making sector, were musical instruments. These however were of little significance due to low demand, and therefore of little economic value (Osogo, 1966).

In other occupations as Sir H.H Johnston pointed out, the Khayo made salt by burning reeds and other water plants and treating the mixture to produce a salty brown cake called muherekha; and the grinding of sorghum flour was done using two stones. Specialization existed in nearly all the crafts and industries except for housebuilding and leather work undertakings (Mary Nyongesa, O.I, 2014).

\section{Education}

In crop and animal husbandry and technological processes, the transmission of ideas was very important. In this section an attempt is made to show that the Khayo had evolved a unique and complex system of education that was very important in their economic production and organization. Indeed, as Tiyembe Zeleza states, education system is one of the most important ideological apparatuses through which the state maintains its control and the relations of production are achieved (Zeleza, 1993).

In Khayo, traditional education was the permanent transmission of knowledge by the older members of the society to the younger ones, with the intention of socializing the youth for adult roles. At the same time, education was important in the conservation of the acquired knowledge. Indeed Odwako (1973) notes that, education took the form of indoctrinating children into their cultural tradition, so that they were adjusted not only to live and serve their society but also to become custodians and future transmitters of their culture. Children's education was the responsibility of members of the society, the family in particular. At birth, children were regarded as important and useful family assets and their education was the responsibility of their mothers and the babysitters, who were supposed to teach the babies good attributes acceptable to the community as a whole. At the age of four to five years, the method of education changed.

As they came to the full understanding of their surroundings, the children gradually separated themselves into boys' and girls' groups. The boys from then henceforth identified themselves with the male adults and learned male activities. At the same time, the girls identified themselves with the female adults and started to master the female roles (Lloyd, 1972). In the evenings after work, children's education was by means of riddles, proverbs, myth, songs and dances. All these carried a special message cherished by the society. The children were expected to live by the virtues of the society as enshrined in the messages and disregard the vices (Lloyd, 1972).

This publication is licensed under Creative Commons Attribution CC BY.

http://dx.doi.org/10.29322/IJSRP.11.09.2021.p11725

WwW.ijsrp.org 
At the age of seven, children were introduced to learning through work (learning by participation). This was so because African pedagogy put a big emphasis on practical learning. The child learned by watching and executing little jobs that immediately became useful to the family and the community.

Thus, the boys went herding, fishing and hunting while the girls became babysitters, drew water and prepared meals. At first, such work was done under supervision but gradually the children were left on their own. By the age of fifteen therefore, the young people were able to perform on their own most of the activities expected of them (Davidson, 1983).

A child was expected to understand the climatic conditions related to his surroundings, for the environment dictated the nature and modes of economic activities that were carried out. Sifuna (1978) notes that, from the earliest years' elders aimed to adapt children to their physical surrounding and to teach them how to use it. Within the homestead and its environs parents and older relatives were responsible for training in economic duties.

In the case of the production of objects, like pottery or smith work, that had practical and cultural value, parents trained their children in a particular art that the family or clan had specialized in. Connected with the economic needs of education were the social needs. Here, the children were taught to understand that they were members of a particular group and therefore, their behavior was supposed to be in conformity with that of the group. Children were thus taught things such as the virtue of sharing common tasks in the field and at home, and the decency of speech and behaviour, plus respect for the older members of the society.

Other issues of great importance in children's education included the study of the community's past and its heroes, plus oral literature that reflected on the people's way of life. In Khayo community there were also many ritual ceremonies, feasts and festivals that were used as means of incorporating the young into the more responsible adult group (Mukhule, 2008).

According to Simiyu (1960), traditional education was mainly transmitted through informal and formal methods of instruction. Among the most prominent methods of informal instruction was play. In this community, the significance of play was generally upheld. Children were consequently allowed to invent games that were attuned to the environment. Apart from play, oral literature also constituted an important method of instruction. This included teaching through myths, legends and folk tales. Children also learned through dance and folksongs. Also, proverbs were used widely in ordinary conversation. Learning through the medium of work was also another informal method of education.

Formal methods of education were particularly pronounced in the theoretical and practical inculcation of skills. For example, learning through apprenticeship was formal and direct as in the case of medicine men; blacksmiths and craftsmen who were apprenticed to work, with the specialists in the given field as helpers. A young person would thus work under the specialist for a number of years before establishing his own workshop (Sifuna, 1985). It is important to note that education in the Khayo community was a lifetime process for it started at birth and ended at death. This was necessitated by the fact that within the society there were new innovations and initiatives every other time, which the society adopted. These compelled everybody to master the new knowledge. All in all, education was a very important ingredient of the traditional economic production system of the Khayo though it was not based in the classroom (Hugh, 1985).

\section{Medical Practice}

Apart from education, the quality of life can also be measured through the provision of health services, which are of course very important for any country's economic development. The Khayo had very precise and clear idea of their nature of diseases and of the treatments required. Therefore, in the traditional Khayo society medicine was very important (Wilson Namenge, O.I, 2014).

Additionally, the Khayo believed that in the everyday life man was confronted by invisible and yet real forces. These forces intervened in the course of events, frustrated one's endeavors and sent him illness and arrest or even death, or they could have been favourable and promoted one's health and material welfare (Mukhule, 2008). Ordinary people, experts or specialists, the spirits of the dead, the supreme beings and a number of minor spirits were all agencies of mystical power. The spirits wielded power actively and consciously or served merely as passive vehicles in which people affected by the spirits resided independent of their own volition (Odulwa Morris, O.I, 2014).

Consequently, the Khayo believed that diseases and accidents were not mere outbreaks, rather, they were sent by agents, either by spirit or sorcerers. However, it is important to note that though magic and herbal medicine were very important elements of protection and prevention in Khayo, they did not dominate the entire field of medicine (Mary Nyongesa, O.I, 2014). Sangree (1966) asserts that most primary causes of diseases were treated or prevented by using very empirical methods. For instance, people who suffered from contagious diseases lived in isolation (in varying degrees) from other members of the family.

In the case of people who suffered from contagious but harmless skin diseases they were not allowed to join the rest of the family in eating and drinking sessions. Such victims had their own utensils to use and slept far away from the rest. People who suffered from

This publication is licensed under Creative Commons Attribution CC BY.

http://dx.doi.org/10.29322/IJSRP.11.09.2021.p11725

WWW.ijsrp.org 
other dangerous diseases that were thought to be infectious like tuberculosis, chickenpox, leprosy, dysentery, bubonic plague and even sleeping sickness were supposed to be in total isolation from the rest of community, for such diseases were thought to be spread by the mere presence of the person suffering from them. Such victims were thus left alone in their huts or special huts were built for them far away from the other houses. Isolation was the most important way of prevention of the spread of contagious diseases. This was in accordance with the belief that such diseases could not be treated by magic or herbal related medicine.

Protective and preventive measures based on the employment of medicine and charms were perhaps the most important forms of disease management in the Khayo society. It was believed that nearly all human misfortune including illness was associated with the mystical forces. Consequently, protective magic and herbal medicine were employed over and above the taking of the ordinary precautions. In taking remedy against misfortune and illness, magical power and herbal medicine were first used in the form of protective agents (equivalent to the modern vaccination methods). Counteraction (curative treatment) of the illness was only employed in case of the failure of the protective measures. Protective magic and herbal medicine were chiefly employed against human agents such as sorcerers and witches (abalosi and abafumu).

Such protective magic and herbal medicine not only warded off the evil intentions of the sorcerers and witches but also offered protection against further misfortunes and illness that could be caused by the same agents. People were also protected against other people's bad intentions or actions (like ill temper, theft, and intrigue) by the use of protective magic, according to Achieng Racheal (O.I, 2014). By virtue of their profession the magic and herbal specialists dealt exclusively in and sold both the protective and curative medicine. The diviners were more important in providing medicine to counteract agents of misfortunes and illness. To the Khayo, the efficacy of an amulet or a medicine increased with increase in the distance of the place from where it was obtained.

People in Bukhayo used various methods against the effects of witches. To become a medicine man or an herbalist, a person was supposed to have either inherited the act of dealing in medicine or be taught by a recognized herbalist or medicine man (Abdulkarim Makokha, O.I, 2014). In case of failure of protective and preventive measures, people resorted to the second line of defense against illness, that is, the counteraction measures and the appeal to higher authority (gods). These two measures were aimed at combating, neutralizing or destroying forces that had become active. Thus, after the causes of misfortunes and diseases were known, the counteraction measures that were appropriate to be taken were automatically determined. However, with a slight deviation from the normal causes of illness, new methods of diagnosis were used.

People were compelled to consult a diviner in various instances, like sudden and violent illness, for example, dysentery, stomach and intestinal trouble, eye diseases and skin eruptions. Persistent diseases, chronic ailment and recurrent pains also needed the attention of the diviner. Also, people sought the advice of the diviner when diseases or dangers threatened the entire clan, for example epidemic and cattle diseases. This is according to Agola Nancy (O.I, 2014).

\section{Division of Labour}

Humphrey (1947) asserted that in the production of goods and services in the traditional Africa, there was a sexual division of labour. Men were responsible for the clearing and opening up of new grounds, building structures, herding and hunting. Women prepared and cooked food, drew water, collected firewood and took care of the children. In addition to the above duties, women also performed the greater and more tedious part of the garden labor. Hoeing, for example, was almost entirely a women's preserve, according to Jane Nabwire (O.I, 2014). Children were also trained at an early age to take their position in the economic production. In the labour organization of the Khayo therefore, there was, the co-operation of all the members of the family.

The labor matters outside the home setting, a wealthy man, for instance could let it be known that he wanted help in the field on a particular day, and he could count on a large body of men and women who would turn out to assist him in whatever task that required extra labor. In return, he was expected to provide large quantities of good food and plenty of beer. The work was normally done in one day and was followed by an evening of conviviality. In case of outside help, the helpers were given plenty of grain in return for their assistance. This was narrated by Odulwa Morris (O.I, 2014).

\section{CONCLUSION}

The study concludes that various activities were associated with social and economic practices among the Khayos in the pre-colonial periods. The social aspects included each family staying together in a homestead, mostly in grass-thatched houses; men and sons were always considered superior to women and daughters; marriage was viewed as sacred where polygamy was allowed; the Khayo believed in 'Were khakaba' and ancestors. The economic activities included community land systems, peasant commodity production with specific areas being hunting, crop production, animal husbandry and barter trade.

This publication is licensed under Creative Commons Attribution CC BY.

http://dx.doi.org/10.29322/IJSRP.11.09.2021.p11725

WwW.ijsrp.org 


\section{ACKNOWLEDGMENT}

I thank God who gave me the strength and courage to undertake this study. My sincere gratitude also goes to my supervisors, Dr. Peter Wafula and Dr. Charles Choti, for their guidance throughout the preparation of this thesis. My special thanks go to Mount Kenya University for enabling me to undertake my studies in the institution. Last but not least I thank all the respondents for the information they provided in making this document a success.

\section{REFERENCES}

Abuso, P.A. (1980) A Traditional History of Abakuria 1400-1914. (Nairobi: Kenya Literature Bureau).

Ajayi, J.., (1968) "The Continuity of African Institutions under Colonialism" in T.O. Ranger (ed.) Emerging Themes of African History (Nairobi: East African Publishing House.

Akurang-Parry, K. (2006). In Memoriam: An Appreciation of Professor A. Adu Boahen (1932-2006)

Black, C. (1966). 'The Dynamics of Modernization, (New York: Harper and Row,), pp. 67 - 68.

Boahen, A. (1990) (ed.) General History of Africa: African Under Colonial Domination 1880 - 1935 Volume 7 California, James Currey.

Bode, F.C. (1978) "Leadership and Politics Among the Abaluyia of Kenya" (Ph.D Dissertation, Yale University,).

Brett, E. (1961). Colonialism and Underdevelopment in East Africa: The Politics of Economic change 1919-1939 (London: Oxford. University Press).

Bukhayo Council of Elders (2010). Proposed Split of Nambale Constituency into two Constituencies and Creating of more wards.

Carlsen, J., (1980) "The Economic and Social Transformation in Rural Kenya" Scandinavian Institute of African Studies.

Central Bureau of Statistics (2005). Geographic Dimension of well-being in Kenya: who and where are the poor? A constituency level profile Nairobi: the regal press (k) LTD.

Clayton and Savage, (1915) "The Leader" (Newspaper) of August 1915, op.cit., p. 8 Clayton and Savage quoting "The Leader" (Newspaper) of August 1915, op.cit., p. 83.

Clayton, A., and Donald C. Savage (1974). Government and Labour in Kenya 1985-1963 (London: Frank Cass).

Constitution of Kenya (2010) promulgated $27^{\text {th }}$ August 2010. Nairobi; Government printers.

Crawford, G. (1995). Decentralization and the Limits to Poverty Reductions: Findings from Ghana.

Oxford Development Studies, $36(2), 235-258$

Curtin, P. (1964). The Image of Africa (Madison: Wisconsin).

Davidson, B. (1978), Africa in Modern History (London: Allen Lane).

Davidson, B. (1983). Modern Africa: A Social and Political History. (London: Longman)

Eelke, J. (2009): Religious Values and Economic growth. A Review and Assessment of Recent Studies.

Ember, Carol R.; Melvin Ember (2003). Encyclopedia of Sex and Gender. New York: Springer. p. 247. ISBN 978-0-306-47770-6.

Étienne, B. (1995). The philosophy of Marx. Verso. p. 56. ISBN 978-1-85984-951-4. Retrieved 8 March 2011. 
Muriuki, G. (1976)."The Kikuyu in the Pre-Colonial Period" in Ogot B.A. (ed.) Kenya Before 1900 (Nairobi: East African Publishing House) p. 107.

GOK (2010). District Developments plan 2008-2012 Nambale sub-county: Economic Survey Report (2012) Nambale Sub- County.

Hopkins, A.G. (1973) An Economic History of West Africa (London: Longman).

Hugh Fearn. (1962) "Population as a Factor in Land Usage in Nyanza Province of Kenya Colony, East Africa"in Agricultural Journal Vol. XX No. 3, pp. 198-210.

Humphrey, N., The Liguru and the Land: Sociological Aspect of Some Agricultural Problems of Northern Kavirondo.

István Mészáros (1 March 2006). Marx's Theory of Alienation. Merlin Press. p. 96. ISBN

Kay, S. (1973) "The Southern Abaluyia: The Friends African Mission and The Development of Education in Western Kenya 19021963 (Ph.D Thesis, University of Wisconsin).

Kenneth, K. (1969), "African and the Southern States of the U.S.A. Notes in J.H. Oldh nad American Negro Education for Africa" Journal of African History, Volume 4, 1969, p. 104.

Kenya Literature Bureau (2018) History and Government Form Three Students' Book (Sixth Edition) Kenya Literature Bureau.

Kenya Bureau of Statistics (2013) "Welcome to Kenya National Bureau of Statistics". Archived from the original on 2011-07-12. Retrieved 2014-04-18.

Kenya National Bureau of Statistics (KNBS) (2008). Kenya integrated house hold budget survey 2005/06 Nairobi: Government printers.

Kenyatta, J. (1961). Facing Mount Kenya: The Tribal Life of The Gikuyu (London; Mercury Book, p. 64

Kitching, G. (1980). Class and Economic Change in Kenya the Making of an African Petit-Bourgeoisie, London: Heinemann.

Lloyd, P.C (1972). Africa in Social Change (Harmondsworth, Penguin).

Makers of Kenyan History; Nabongo Mumia, Heinemann Kenya, ISBN 9966-46-808-0

Mamdani, M. (1996) Citizen and Subject: Contemporary Africa and the Legacy of Late Colonialism, Kampala: Fountain Publishers.

Marx K (1999). "The labour-process and the process of producing surplus-value". In K Marx, Capital (Vol. 1, Ch. 7). Marxists.org. Retrieved 20 October 2010. Original work published 1867.

Mukhule O. (2008). Amakesi ka Bakhulundu (Wisdom of Elders)

Mukhule O. (2008). The History and Culture of the Abahero People of Western Kenya.

Munro, J. (1984) Britain in Tropical Africa 1880-1960: Economic Relationship and Impact (London: Macmillan Press).

Munro, J., (1984) Colonial Rule and the Kamba (Oxford: Clarendon Press

Ndege, P. (2009) “An Assessment of Poverty Reduction Strategies in Kenya”, Organization for Social Science Research in Eastern and Southern Africa (OSSREA), Assessment of Poverty Reduction in Sub-Saharan Africa: The Case of Kenya, Addis Ababa: OSSREA.

Odwako, O. (1973) "The Church and Education: The Contribution of the Church Missionary Society to Education in Western Kenya 1905-1963",(Ph.D Thesis, University of Nairobi).

This publication is licensed under Creative Commons Attribution CC BY.

http://dx.doi.org/10.29322/IJSRP.11.09.2021.p11725

www.ijsrp.org 
Ogot, B. (1976). Zamani A Survey of East Africa History (East African Publishing House and Longman)

Ogot, B. \& Ochieng, W. (Eds.) (1995) Decolonization and Independence in Kenya, 1940-1993, London: James Currey.

Ogot, B. (2000) "Boundary Changes and the Invention of "Tribes", Ogot, B. A. and Ochieng, W. R. (Eds.) (2000) Kenya: The Making of a Nation, Maseno: Institute of Research and Postgraduate Studies (pp 16-31)

Ogutu, M \& Kenyanchui, P. (1991). An Introduction to African History (Nairobi University Press)

Osogo, J. (1966). A History of the Abaluyia (London: Oxford University Press).

Painter, K.L (1951). The Hill of Vision: The Story of the Quaker Movement in East Africa 1902-1965 (Nairobi: English Press).

Pierre (1956) Shifting Cultivation in Africa (London: Longman) pp. 84 - 85, 119 - 21.

Rodney, W. (1989) How Europe Underdeveloped Africa. (Nairobi: Heinemann)

Rowe, J. (1961) "Kaimosi: An Essay in Missionary History" (Unpublished)

Sangree, H. (1966). Age, Prayer and Politics in Tiriki (London: Oxford University Press.

Sheriff, H. (1985) "Social Formations in Pre-colonial Kenya", Ogot, B.A. (Ed.) Hadith 8: Kenya in the 19th Century. Kisumu: Anyange Press (pp.1-31)

Sifuna, D. (1978) "Some aspects underlying Christian missionary educational activities in Kenya in 1844-1900" in Historical Association of Kenya (Annual Conference, August 1978).

Sifuna, D. (1977) "The Maragoli and the Tiriki of the Abaluyia of Western Kenya: Contrasting Features in Response to Christianity and Western Education"in Historical Association of Kenya, Annual Conference August 1977.

Simiyu, V. (1966).” Traditional Methods of Education in East Africa" In Presence Africaine No. 807, p. 180.

Smith, H. (1975) Strategies of Social Research: The Methodological Imagination. London: Prentice Hall.

Survey of Kenya Nairobi (1984). Published by Survey of Kenya.

Wagner, G., (1939). The Changing Family Among the Bantu Kavirondo (London: Oxford University Press.

Wambunya, T. (2007). "'ABA' LUYIA" (PDF). Retrieved 25 April 2014.

Were, G (1967). East Africa through 1000 years (London Evans Brothers Ltd)

Willoughby, J. (1889). East Africa and Its Big Game. (London: Longman).

Wolff, R. (1974). The Economics of Colonialism: Britain and Kenya, 1879-1930. Nairobi: Trans Africa Press.

Wrigley, C. (1965). Kenya: The Patterns of Economic Life 1902-45

Zeleza, T. A. (1963). Modern Economic History of Africa: The nineteenth century, (Nairobi: East Africa publisher). International Journal of Education and Research Vol. 4 No. 4 April 2016 


\section{AUTHORS}

1) Kaunda Kenneth K. Odulwa - A Master of Arts (History) student in the Department of Languages and Humanities at Mount Kenya University

2) Dr. Peter Wafula - Senior lecturer in the Department of Humanities at Kenyatta University

3) Dr. Charles Choti - Senior lecturer in the Department of Languages and Humanities at Mount Kenya University

Corresponding Author, Kaunda Kenneth K. Odulwa Email: odulwakenneth@yahoo.com 